\title{
A Comparison of the Incentives Used to Stimulate Energy Production in Japan, France, West Germany, and the United States
}

June 1981

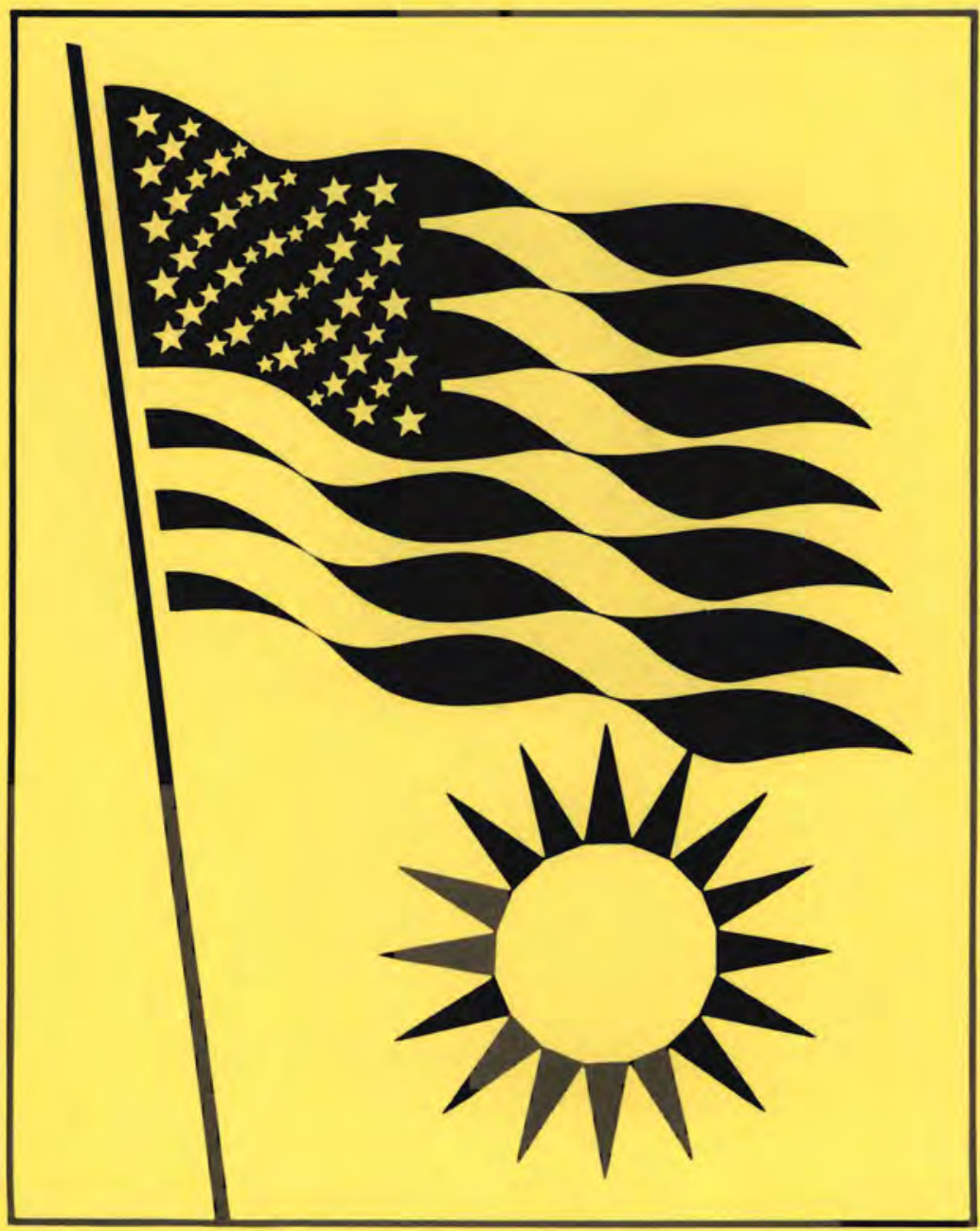

Prepared for the U.S. Department of Energy under Contract DE-AC06-76RLO 1830

Pacific Northwest Laboratory

Operated for the U.S. Department of Energy by Battelle Memorial Institute 
This report was prepared as an account of work sponsored by the United States Government. Neither the United States nor the Department of Energy, nor any of their employees, nor any of their contractors, subcontractors, or their employees, makes any warranty, express or implied, or assumes any legal liability or responsibility for the accuracy. completeness or usefulness of any information, apparatus, product or process disclosed, or represents that its use would not infringe privately owned rights.

The views, opinions and conclusions contained in this report are those of the contractor and do not necessarily represent those of the United States Government or the United States Department of Energy.

\author{
PACIFIC NORTHWEST LABORATORY \\ operated by \\ BATTELLE \\ for the \\ UNITED STATES DEPARTMENT OF ENERCY \\ Under Contract DE-AC06-76RLO 1830
}

\author{
Printed in the United States of America \\ Available from \\ National Technical Information Service \\ United States Department of Commerce \\ 5285 Port Royal Road \\ Springfield, Virginia 22151
}

Price: Printed Copy \$

$\because$ Microfiche $\$ 3.00$

NTIS

-Pages Selling Price

$\begin{array}{lr}001-025 & \$ 4.00 \\ 026-050 & \$ 4.50 \\ 051-075 & \$ 5.25 \\ 076-100 & \$ 6.00 \\ 101-125 & \$ 6.50 \\ 126-150 & \$ 7.25 \\ 151-175 & \$ 8.00 \\ 176-200 & \$ 9.00 \\ 201-225 & \$ 9.25 \\ 226-250 & \$ 9.50 \\ 251-275 & \$ 10.75 \\ 276-300 & \$ 11.00\end{array}$


PNL-3788 Ex. Sum.

UC -59

A COMPARISON OF THE INCENTIVES

USED TO STIMULATE ENERGY PRODUCTION

IN JAPAN, FRANCE, WEST GERMANY, AND

THE UNITED STATES

An Executive Summary
R. J. Cole
B. W. Cone
P. Sommers
C. Eschbach
W. J. Sheppard
D. E. Lenerz
M. Huelshoff
A. A. Marcus

June 1981

Prepared for

the U.S. Department of Energy

under contract DE-ACO6-76RLO 1830

Pacific Northwest Laboratory

Richland, Washington 99352 
. 


\title{
A COMPARISON OF THE INCENTIVES USED TO STIMULATE ENERGY PRODUCTION IN JAPAN, FRANCE, WEST GERMANY, AND THE UNITED STATES
}

\author{
An Executive Summary
}

In this Executive Summary we summarize the conclusions of each of our three non-U.S. incentives volumes, ${ }^{(1)}$ and the conclusions of the comparisons volume which looks at incentives in four countries including the United States. (2) Summaries of the patterns of incentive actions in France, West Germany, and Japan are presented first, followed by a summary of the four-country comparisons volume itself. The final section of this Executive Summary contains suggestions for solar policy which are based on our comparison of incentive actions in the four countries.

The definitions and methods used in each of the single-country studies are explained in detail in those volumes. Here we offer the following brief explanation of the procedures. Each volume was divided into three parts: a survey of current thought about incentives for solar energy production; a view of the energy incentive landscape for one particular year; and an analysis of the major energy forms (nuclear, hydro, coal, electricity, oil, and gas) along the path from exploration to waste management, including the costs of incentives at each step in constant national currency.

Following the theoretical approach developed for studying U.S. energy incentives, the researchers in each country classified incentives into the following six categories: (1) Taxation, including exemption from or reduction of existing taxes; (2) Disbursements, in which the national government distributes money without requiring anything in return; (3) Requirements, including demands made by the government, backed by civil or criminal sanctions; (4) Traditional Services, including those almost always provided exclusively by a govermental entity; (5) Nontraditional Services, including those sometimes performed by non-governmental entities, as well as governmental entities (e.g., reasearch and development); and (6) Market Activities, including 
government involvement in the market under conditions similar to those faced by non-governmental producers or consumers.

\section{FOREIGN INCENTIVES SUMMARY}

\section{France}

In France, three conditions are important to keep in mind in interpreting the pattern of incentives given to energy production:

0 the great share of imports in French energy supplies

o state ownership of underground resources and

- state ownership of equity in the major energy companies, and state operated energy producing entities.

Imports accounted for $32 \%$ of French energy supplies in 1949, and this share has grown to about $75 \%$ at present. Two governmental entities provide funds for energy production activities: the Caisse nationale de l'energie (CNE), and the Fonds de developpement economique et social (FDES). The CNE provides funds to public companies to carry out their investment programs, and manages security offerings of public companies. The FDES gives specific approval to investments suggested by such public companies as Electricite de France, the national electric generation utility, and Gaz de France, the national gas and electricity service company.

A total of $\$ 24.8$ billion was spent for energy production incentives in France (see Tables 1 and 2). About $45 \%$ of these incentives went to nuclear power. These funds consisted of research and development funds, loans, and assistance in uranium prospecting. A substantial nuclear power industry exists in France with production of over 37,000 gigawatt hours in 1979.

Hydroelectric power has received incentives totaling about $\$ 1.4$ billion. These funds were used for the construction of publicly owned hydroelectric facilities and for regulation of the power producing entities. Much of the incentive funding was in the form of loans and direct subsidies to the operating entities. 
TABLE 1. Commulative Tptal Incentive Expenditures $(1950-1976)(a)$ in 1976 Dollars

\begin{tabular}{|c|c|c|c|c|c|}
\hline & France & Germany & Japan & $\begin{array}{l}\text { United } \\
\text { States }\end{array}$ & Total \\
\hline Nuclear & 11,864 & 7,389 & 5,862 & 15,297 & 39,810 \\
\hline Hydroelectric & 1,456 & 19 & 14,757 & 14,020 & 30,252 \\
\hline Coal 1 & 6,088 & 39,142 & 9,287 & 8,112 & 62,629 \\
\hline $0 i 1$ & 2,367 & 1,219 & 535 & 83,570 & 100,553 \\
\hline Natural Gas & 747 & 3,268 & 2,409 & 14,310 & 20,734 \\
\hline Electricity & 2,265 & 2052 & 752 & 51,760 & 56,829 \\
\hline TOTAL & 24,787 & 53,089 & 33,807 & 187,070 & 298,753 \\
\hline $\begin{array}{l}\text { Total Incentives } \\
\text { Per Quad Produced }\end{array}$ & 16,307 & 11,320 & 17,874 & 3,304 & \\
\hline $\begin{array}{l}\text { Total Incentives } \\
\text { Per Capita (1976) }\end{array}$ & 477 & 871 & 300 & 870 & \\
\hline $\begin{array}{l}\text { Total Incentives } \\
\text { Per Dollar of } \\
1976 \text { GDP }\end{array}$ & 0.08 & 0.12 & 0.06 & 0.11 & \\
\hline
\end{tabular}

(a) Data on incentives spending begin in different years in each country. 1950 is the approximate date for all four countries. 
TABLE 2. Incentive Expenditures by Energy Form as Percent of Cumulative Total Incentives, 1950-1976(a)

\begin{tabular}{lrrrrr}
\hline & France & Germany & Japan & $\begin{array}{c}\text { United } \\
\text { States }\end{array}$ & Average (b) \\
\hline Nuclear & 47.86 & 13.92 & 17.5 & 8.18 & 21.87 \\
Hydroelectric & 5.88 & 0.04 & 43.9 & 7.49 & 14.33 \\
Coa & 24.56 & 73.73 & 27.6 & 4.34 & 32.56 \\
Oil & 9.55 & 2.30 & 1.6 & 44.67 & 14.53 \\
Natural Gas & 3.01 & 6.15 & 7.2 & 7.65 & 6.00 \\
Electricity & 9.14 & 3.86 & 2.24 & 27.67 & 10.73 \\
Total & 100.00 & 100.00 & 100.00 & 100.00 & 100.00
\end{tabular}

(a) Data on incentives spending begin in different years in each country. 1950 is the approximate date for all four countries.

(b) Average is the sum of the rows divided by 4 .

Coal received incentives of slightly over $\$ 6$ billion, about $25 \%$ of the total incentive spending in France. The coal companies are nationalized in France; hence, most of these funds are for the operation of the public companies. These companies operated at a loss and required subsidy from the state. Funds were also provided for research and development.

0 il received over $\$ 2$ billion in incentives, about $10 \%$ of the total incentive spending in France. These funds were for research and development, exploration, and construction of ports to facilitate oil imports. The objectives of French oil policies have been to develop whatever domestic resources are available, and to control energy supplies located outside of France.

Natural gas received only $\$ 747$ million in incentives, just $3 \%$ of the total incentive spending. France has quite limited gas resources, limiting the ability of the state to stimulate gas production. The French 
state has provided incentives in the form of capital grants and loans to the national gas distribution utility, Gaz de France.

The electricity sector received incentives of almost 2.3 billion, about $9 \%$ of the total incentives. The electric power sector was nationalized in France after World War II. The national electric utility, Electricite de France, receives incentives in the form of disbursements to facilitate rural electrification, state guarantees for loans to the national utility, research and development funds, and low-interest loans from the FDES.

The distribution of French energy incentives by incentive type across all energy forms (see Tables 3 and 4 ) reveals a heavy concentration of incentive funds in the disbursements category $(72.0 \%)$, with a secondary emphasis on market activities (24.8\%). Nontraditional services, especially research and development, have been provided, accounting for $2.5 \%$ of incentive spending, and traditional services account for just $0.4 \%$ of the incentive spending.

From 1975 to 1979, the French government has been giving incentives specifically for solar energy. Starting in 1975, $91 \%$ of these incentives were for research and development, while this proportion falls to $67 \%$ by 1979. Subsidies and demonstration projects accounted for just $9 \%$ of the solar budget in 1975, but this category has grown to about $33 \%$ of the budget as of 1979. A variety of technologies has received incentives, including solar thermal power stations, photovoltaic cells, water and space heating technologies, and biomass technologies. A special subsidy is offered for solar water heating applications starting in 1979.

\section{West Germany}

In Germany, a total of over $\$ 53$ billion has been spent on energy production incentives. Nearly $\$ 7.4$ billion of these incentives were for nuclear power, just under $14 \%$ of the total incentive spending (see Tables 1 and 2). These funds were used for basic and applied nuclear research, uranium prospecting and other fuel cycle activities, construction of prototype and demonstration plants, reactor safety research, provision of liability insurance, and public information 
TABLE 3. Cumulative Incentive Expenditures (1950-1976) by Incentive Type in Millions of 1976 Dollars(a)

\begin{tabular}{lrrrrr}
\hline & France & Germany & Japan & $\begin{array}{l}\text { United } \\
\text { States }\end{array}$ & Total \\
\hline Taxation & (b) & 9,095 & 341 & 93,610 & 103,046 \\
Disbursements & 17,936 & 35,795 & 5,105 & 930 & 59,766 \\
Requirements & (b) & (b) & 1,153 & 31,520 & 32,673 \\
Traditional Services & 95 & (b) & 229 & 7,880 & 8,204 \\
Nontraditional & 614 & 7,613 & 4,083 & 16,327 & 28,637 \\
Services & & & & & \\
Market Activity & 6,142 & 586 & 22,897 & 36,810 & 66,427 \\
Total & 24,787 & 53,089 & 33,807 & 187,070 & 298,753 \\
\multicolumn{1}{c}{ Average (c) } & 6,197 & 13,272 & 5,635 & 31,178 & 49,792
\end{tabular}

(a) Data on incentives spending begin in different years in each country. 1950 is the approximate date for all four countries.

(b) Not quantified in source.

(c) Average is the sum of the columns divided by the number of elements that are quantified. 
TABLE 4. Incentive Expenditures by Incentive Type as percent of Cumulative Total Incentives, $1950-1976$ (a)

\begin{tabular}{lccrrr}
\hline & France & Germany & Japan & $\begin{array}{r}\text { United } \\
\text { States }\end{array}$ & Average(c) \\
\hline Taxation & (b) & 17.13 & 1.0 & 50.04 & 23.19 \\
Disbursements & 72.3 & 67.42 & 15.1 & .50 & 38.83 \\
Requirements & $(\mathrm{b})$ & $(\mathrm{b})$ & 3.4 & 16.85 & 10.13 \\
Traditional Services & 0.4 & $(\mathrm{~b})$ & .7 & 4.21 & 1.77 \\
Nontraditional & 2.5 & 14.34 & 12.1 & 8.72 & 9.42 \\
Services & & & & & \\
Market Activity & 24.8 & 1.1 & 67.7 & 19.67 & 28.32 \\
Total & 100.00 & 100.00 & 100.00 & 100.00 &
\end{tabular}

(a) Data on incentives spending begin in different years in each country. 1950 is the approximate date for all four countries.

(b) Not quantified in source.

(c) Average is the sum of each row divided by the number of elements.

campaigns attempting to increase public acceptability of nuclear power. The result is a German nuclear power technology which can compete economically with fossil fuels, and a technology which can be exported.

Hydroelectric incentives accounted for barely $0.04 \%$ of German energy incentives, due to a paucity of suitable hydroelectric resources. In the state of Bavaria, hydropower accounts for $10 \%$ of electricity generation. In the other German states, much smaller proportions of power production are due to hydroelectric facilities. The $\$ 19$ million in total hydroelectric incentives were provided through a variety of tax relief schemes.

Coal received a total of over $\$ 39$ billion in incentives, nearly $74 \%$ of the total incentive spending in Germany. The coal incentives are designed to encourage productivity in the industry, to provide research and development for the industry, and to improve transportation systems. 
Recently, coal gasification and liquifaction have received increased emphasis in the research and development budget. Despite these incentives, the coal sector has shrunk in terms of the percentage of contribution to total energy consumption in Germany from about $78 \%$ in 1950 to just $29 \%$ in 1975. A major concern of the coal incentive program has been the orderly management of the decline of the industry.

$0 i 1$ has received only about $\$ 1.2$ billion in incentives, just $2.3 \%$ of total incentive spending in Germany. This level of incentives reflects the fact that Germany has very few domestic oil resources, and is very dependent on oil imports to keep the economy going. The incentive funds have been used for research and development on prospecting and oil recovery technologies, for exploration and production, and for refining and safeguarding energy supplies. The incentives have taken the form of disbursements, requirements, and nontraditional services.

Natural gas received somehwat more incentive funds than oil, about $\$ 3.3$ billion or about $6 \%$ of total energy incentive funds. Only very small quantities of natural gas had been discovered in Germany until the mid-1960s, after which North Sea gas discoveries have resulted in an increased share of gas in total primary energy consumption. Incentives offered to the sector include research and development on exploration and recovery methods, subsidies to promote exploration and recovery, and granting of monopoly rights to gas pipeline companies.

Incentives to the electric power sector in Germany amounted to over $\$ 2$ billion, about $4 \%$ of total incentive expenditures. Both district heating and electric power production incentives are included in these figures, since the same entities provide both types of outputs. Requirement incentives to the industry include price controls. Market activity incentives include government equity positions in the electric power companies. In addition, certain tax privileges are granted to the electric utilities. Nontraditional services, including research and development on district heating technologies, have been important incentives to the industry as we11. Research and development on district heating have been funded only since 1974 . 
Looking at the distribution of incentive expenditures in Germany by incentive type across $a 11$ energy forms (see Tables 3 and 4), the largest incentive type is disbursements, with over $67 \%$ of total incentive funds. Taxation accounts for $17 \%$ of the incentives, while nontraditional services constitute a bit over 14\%. Market activity incentives constitute a very small proportion of the total, with just over $1 \%$ of incentive funds. While both requirement and traditional service incentives are offered to the energy industries in Germany, it was not possible to quantify the incentives of these types.

As in France, the German government is beginning to develop programs for encouraging solar power applications, and incentives are included in these programs. Beginning in 1974, research and development funds were allocated for solar technologies, amounting to $49 \mathrm{million}$ German Marks over the period 1974 to 1977 . Subsidies have been offered for solar technologies, starting in 1978 with a funding level of 8.5 million Marks. In addition, programs of income tax deductions and direct subsidies have been started in recent years.

$\underline{\text { Japan }}$

The Japanese incentives volume covers the period from 1945 to 1976. Four distinct periods with different energy policies are distinguished:

- 1945-1951, a period of control over energy by the American military officials who assumed control of Japan after the Second World War

- 1951-1960, a period in which the coal industry was protected from incursions by lower-priced oil

- 1960-1972, a period in which cheap oil became the primary energy source, with coal receding in importance, and

- 1973-1976, a period in which energy conservation assumed new importance.

Over this entire period of time, a total of 33.8 billion U.S. dollars was spent to encourage the production of various forms of energy (see Tables 1 and 2).

The nuclear industry received 5.9 billion of these incentive dollars, about $17.5 \%$ of the total incentives. These funds took the form of disbursements for research and development programs, research and 
development which was conducted by the government itself, provision of liability insurance for reactor operators, subsidies for uranium exploration, and creation of a public entity which conducts uranium exploration. In addition, tax incentives are provided to the nuclear industry and government grants are provided for nuclear power plant construction (see Tables 3 and 4 ).

Hydroelectric power has received incentives totaling nearly $\$ 15$ billion, and accounting for nearly $44 \%$ of the total incentive dollars. These funds are used for the construction and operation of hydroelectric facilities, including transmission facilities as well as the generating plants.

Coal, an energy source whose importance has varied greatly within the period studied in Japan, received a total of $\$ 9.3$ billion in incentive funds, about $28 \%$ of the total incentive funds. The incentive dollars have been used alternately to increase production of coal immediately after the war, and to rationalize coal production in the face of declining demand in later years. The incentives have taken the form of research and development funds, tax exemptions for mining operations, disbursements to aid in closing down mines, disbursements to aid the industry's pollution control efforts, and various types of market activity.

$0 i 1$ and gas incentives in Japan amounted to a total of $\$ 2.9$ billion, or about $8.8 \%$ of total incentive funds. These incentives included research and development funds, exploration and production services, market activity carried out by entities of the government, tax exemptions for the refining and transportation of $0 i 1$, special interest subsidies for oil tanker construction, and construction of oil tanker ports.

The electric power sector has received over 700 million in incentives, about $2 \%$ of the total incentive funds. These funds have been used to encourage development of geothermal power plants. Exploration and environmental impact assessments have been provided by the government, loans have been provided to geothermal resource development agencies, and grants were provided for research and development activities in the geothermal area. 
Japan concentrates its incentive expenditures in market activities as $67 \%$ of Japan's total expenditures are made in this incentive type (see Tables 3 and 4 ). The rest of Japanese expenditures are largely accounted for in disbursements and nontraditional services. Fifteen percent of incentive spending is done through disbursements and $12.1 \%$ is spent in nontraditional services. Interestingly, taxation incentives constitute only $1 \%$ of Japan's energy expenditures and traditional services constitute even a smaller percent (.7) of total expenditures. Finally, requirements account for a measurable but small percent (3.4) of total incentives in Japan.

In Japan, solar energy is now encouraged through the "Sunshine Project," a program of the Ministry of Industry and Technology. The funds disbursed by Sunshine Project will result in the creation of solar development organizations. In addition, a solar energy development corporation, a public entity, will carry out research and development and market activities in the solar energy field. Special depreciation allowances for solar equipment are provided as a tax incentive, and some existing hydroelectric dams are to be fitted with solar panels to provide an additional energy output.

COMPARISON OF ENERGY INCENTIVES IN FRANCE, WEST GERMANY, JAPAN, AND THE UNITED STATES

The major focus of the comparisons volume is on comparing the patterns of incentives used to stimulate the production of energy in the four countries we have studied. A summary of findings of this comparisons volume is presented below, followed by a discussion of the implications of these results for solar policy in the United States.

Energy consumption and production patterns in each of the four countries vary considerably across the four countries. Total energy consumption in the United States is over five times as high as that in Japan, seven times as high as that in West Germany, and nearly ten times higher than that of France. $0 i 1$ is the most important fuel in all four of these countries. Coal is the second most important fuel in France, West Germany, and Japan, followed by natural gas. In the United States, 
natural gas is more important than coal as a fuel source. The United States is the most nearly energy independent, with $78 \%$ of its requirements provided by domestic production. West Germany meets $43 \%$ of its needs with domestic production, while France produces just $24 \%$ of its requirements, and Japan, on $1 y$ 14\%. Energy production, industry, transportation, and residential sectors each account for between 19 and $27 \%$ of energy consumption in the United States, while commercial and other sectors account for just $6 \%$ in total. In the other three countries, industry consumes a larger portion of total energy consumption, ranging from $30 \%$ in West Germany to $43 \%$ in Japan. Comparing the three foreign countries to the United States, energy production accounts for a similar proportion of energy consumption, as in the United States, while transportation accounts for much less energy consumption in the three foreign countries.

Residential consumption in the other three countries brackets that of the United States, with Japan using less in this sector, and France and West Germany using somewhat more. The commercial and other sectors are similar in their energy consumption abroad and in the United States.

The institutional context of the four countries is also quite varied. Data on the demographic composition and trends in each of the countries show that the population of the United States is twice that of Japan, and three to four times that of West Germany and France. In addition, population density in the United States is drastically lower than that of any of the other countries. Transportation energy use is much higher than in the other countries because our large population is spread out over a large area. Data on government structure and policy-making show that Japan and France have governments relatively centered on the executive branch, with more direct participation in economic and energy activities; West Germany and the United States have governments more balanced across the executive and legislative branches and less direct participation in economic and energy activities.

Comparisons of the level of energy incentives, energy form by energy form, across the four countries suggest that the resource base and level of economic activity in each country are major determinants of incentive actions. The United States has excellent energy resources and a very high 
level of economic activity. It has also spent more on incentives than any other country, but at a relatively low cost per quad of energy. French spending for nuclear incentives is quite high, even in dollars per quad of energy produced, perhaps because of a need to satisfy consumer preferences for electric power over other energy forms. German spending on coal incentives seems to be an attempt to compensate for the social costs of the mining process, especially when it becomes necessary to close down older facilities. In Japan, incentive programs reflect the paucity of domestic energy resources, and the necessity to exploit aggressively whatever resources are available, as well as to protect outside sources of energy supply.

A comparison of incentives by incentive type across the four countries demonstrates that each country has tended to emphasize one or two incentive types quite heavily, placing less emphasis on the others. Different emphases were chosen by each of the countries. France relied almost exclusively on disbursements and market activity. In Japan, market activity is emphasized with secondary reliance on disbursements. West Germany has relied mainly on disbursement incentives, backed up by tax and service programs. In the United States, taxation incentives, requirements and market activities have been extensively used. A comparison of incentive costs with the percentage going to market activity suggests that this incentive type is relatively expensive, although desirable because it can be precisely directed. Associations of institutional conditions with incentive type emphases reveal that more centralized governments are likely to choose market activity or disbursement incentives as their major incentive type, while taxation, requirements, and disbursements are chosen as the major emphasis by the less centralized countries.

\section{CONCLUSIONS FOR SOLAR POLICY}

The comparison of energy incentives across four countries shows that the pattern of incentives spending by energy form and by incentive type varies considerably. The patterns of incentives appear to be related to both resource conditions in these countries and to the institutional environments within which governments operate. It is likely that solar 
policy, too, will have to be adapted to resource conditions and to institutional constraints. Just as it makes more sense to stimulate the production of $0 i 1$ at locations where good $0 i 1$ resources can be found, it makes sense to stimulate the conversion of solar energy only in areas where good solar resources are available. The mix of incentives used to accomplish this task must be sensitive to prevailing institutional conditions in the country. Thus, past patterns of spending on incentives in the United States may be good guides to the kinds of incentives which should be considered for solar energy forms.

However, solar policy-makers should not feel unduly constrained by historical incentive spending patterns in any one country such as the United States. The fact that we have studied only four countries means that the associations we have found between resource conditions and incentive spending, and between institutional contexts and incentive-type choices, should be regarded as tentative and suggestive rather than as well-tested and relatively immutable social "laws." The very fact that different incentive choices have been made in the four countries we have studied indicates that different emphases in incentives can be considered as feasible. Unless further investigations reveal reasons why the present pattern used in the United States cannot be changed and bettered, one should regard the alternative patterns found in the other countries as options to be considered in formulating solar policy for the United States.

A final point is that every country we have studied has devoted significant resources to stimulating the production of traditional energy forms. None of these countries has allowed the "invisible hand" of the market to be the sole determinant of energy production decisions for the country. For reasons of national security and public economic policy, all four countries have chosen to intervene in the energy marketplace. Governmental intervention therefore may be required for solar energy, if only to counteract effects of incentives given to traditional energy forms. Even if existing incentives to these forms were removed, their past existence has cumulative and continuing effects into the future. In addition, in the wor ld market, new energy forms will have to compete with forms subsidized by other countries. Finally, the national security and 
public policy concerns that led to the original interventions in the traditional energy sector markets may call for intervention in this market as we 11 . 


\section{NOTES}

1. C. Massetti et al., An Analysis of French Incentives Used to Stimulate Energy Production. Draft report for U.S. Department of Energy by Pacific Northwest Laboratory, January, 1981. 0. Ozeki et al., An Analysis of Japanese Incentives Used to Stimulate Eneray Production. Draft report for the U.S. Department of Energy by Pacific Northwest Laboratory, July, 1980. S. van Buiren et a1., An Analys is of West German Incentives Used to Stimulate Energy Production. Draft report for U.S. Department of Energy by Pacific Northwest Laboratory, August, 1980. These volumes are in draft form and available at reproduction cost from $R$. J. Cole at Battelle Human Affairs Research Centers, 4000 N.E. 41st Street, Seattle, WA 98105. Our volume on U.S. incentives has its own Executive Summary: An Analysis of the Results of Federal Incentives Used to Stimulate Energy Production. Executive Summary. U.S. Department of Energy. February, 1981.

2. R. J. Cole et al., A Comparison of the Incentives Used to Stimulate Energy production in Japan, France, West Germany, and the United States. Report for the U.S. Department of Energy by Pacific Northwest Laboratory (PNL-3788), March, 1981. 
PNL-3788 Ex. Sum. UC -59

\section{DISTRIBUTION}

No. of

Copies

OFFSITE

A. A. Churm

DOE Patent Division

9800 S. Cass Avenue

Argonne, IL 60439

25 James C. Easterling

DOE Division of Conservation and Solar Energy

Office of Solar Applications for Industry

600 E Street N.W.

Washington, DC 20585

27 DOE Technical Information Center

Robert L. Sears

Associate Director, ASEC

$1700 \mathrm{~W}$. Washington, \#502

Phoenix, AZ 85007

Michael Saba

Theodore Barry \& Associates

1520 Wilshire

Los Angeles, CA 90017

Gerald Bennington

Bennington Enterprises, Ltd.

P. 0. Box 866

Vienna, VA 22180

John Emery

Bonneville Power Administration

Box 3621

Portland, OR 97208

William Babcock

Booz, Allen \& Hamilton, Inc. 311 First Street, N.W.

Washington, DC 20001
No. of

Copies

Richard Chew

300 Radio Building

2030 North 16th Street

Arlington, VA 22201

Bruce W. Cone

Rt. 2, Box 2142

Benton City, WA 99320

2 Jeff Hammarlund

U.S. Department of Energy

CS-PP\&E

$\mathrm{Rm}$ 6B-042

Mai1 Stop 6B-025

1000 Independence Avenue, S.W.

Forrestal Building

Washington, DC 20585

Mr. Charles R. Hauer

U.S. Department of Energy

1000 Independence Avenue S.W.

Washington, DC 20585

Lee Johnson

U.S. Department of Energy, Region $X$

1992 Federal Building

915 Second Avenue

Seattle, WA 98174

Dr. Roger Bezdek

Department of Treasury

15 th and Penn N.W.

Room 4120

Washington, DC 20220

Sarah Glazer

Subcommittee on Energy and Development Applications

B374 Rayburn House Office Building Washington, DC 20515 
No. of

Copies

James W. Spensley

Staff Director

Subcommittee on Energy and Development Applications

B374 Rayburn House Office Building

Washington, DC 20515

Arthur J. Reiger

Director of Financial Analys is

HUD Solar Demonstration Program

Department of Housing and Urban Development

Room 8158

Washington, DC 20410

Rosalyn Barbieri

Jet Propulsion Laboratory

4800 Oak Grove Drive

Pasadena, CA 91103

James Maxwe 11

Massachusetts Institute of

Technology

Center for Policy Alternatives

Cambridge, Massachusetts 02139

Alex Maurizi

1344 Fitch Way

Sacramento, CA 95825

Michael Huelshoff

Department of Political Science

University of Michigan

Ann Arbor, MI 48109

Michael Shulman

W392

The MITRE Corporation

1820 Dolly Madison Boulevard

McClean, VA 22012

Alan Miller

Natural Resources Defense Council

1725 I Street, N.W.

Suite 600

Washington, DC 20006
No. of

Copies

Eric 01son

Northeast Solar Energy Center

470 Atlantic Avenue

Boston, MA 02110

Thomas Sparrow

School of Industrial Engineering Grissom Hall

Purdue University

West Lafayette, IN 47907

Jon M. Veige 1

SERI

1617 Cole Boulevard

Golden, C0 80401

Barbara Euser

Solar Energy Research Institute

1536 Cole Boulevard

Golden, Colorado 80401

John N. Nassikas

Squire, Sanders and Dempsey

21 Dupont Circle N.W.

Washington, DC 20036

Raymond G. Anderson

Washington State Energy Office

$400 \mathrm{E}$. Union Street, 1st Floor

01 ympia, Washington 98504

Dr. Leon Lindberg, Professor

Department of Political Science University of Wisconsin-Madison 1050 Bascom Hall

Madison, WI 53706

\section{ONSITE}

DOE Richland Operations Office Programs Division

H. E. Ransom 
No. of

Copies

73 Pacific Northwest Laboratory

P. Cohn

T. Willke (10)

R. Cole (HARC) (10)

D. Deonigi (35)

J. Emery

A. Fassbender

H. Harty

A. Marcus

R. Mazzucchi

P. Petty

P. Sommers (HARC)

L. Williams

Technical Information (5)

Publishing Coordination RO (2)

Barbara Keen (HARC) (2)

11 Battelle-Columbus Laboratories

D. Lenerz

W. Sheppard (10)

FOREIGN

Battelle-Geneva

Claude Massetti

Battelle-Frankfurt

Shirley Van Buiren 
